Secondly, I would appeal for a wider co-operation of Ophthalmologists throughout Australia, and the Empire. In Australia there is little or none. Such co-operation can only result in greater cohesion between, and greater knowledge of, the integral parts of our great Empire.

A profound ignorance of the nationality, situation, and population of Tasmania which exists throughout the world is probably mostly due to the remoteness of the island, and if this paper serves no other purpose than to bring Tasmania to the notice of Ophthalmologists throughout the Empire, then I shall be more than satisfied.

And lastly I must offer my gratitude to the Surgeons of Moorfields, whose stimulating guidance in past years has made this work possible to-day.

\title{
ACCOMMODATION IN THE EYES OF MAMMALS
}

BY

\author{
Sir JaMES BarRetT \\ MELBOURNE
}

THE excellent account of the theories of accommodation published by Edgar F. Fincham opens up, incidentally, the old question of whether mammals, other than primates, can accommodate at all or if so only to a negligible extent.

A great deal of experimental work has been done, and in some cases by experienced physiologists on the eyes of animals which certainly have no useful accommodation, and some erroneous conclusions have been drawn from such experimental work. Nothing is more dangerous in dealing with biological problems than the argument from analogy and also from the assumption of a supposed uniformity of type in the animal kingdom.

I venture therefore to set out briefly the history of the efforts made to ascertain what takes place in the eyes of mammals, other than primates. When the ciliary muscle was discovered by Bowman and Bruecke after 1840, and Helmholtz had in consequence developed the classical theory of accommodation, those interested (possessing the mentality of the period) assumed that the eyes of all mammals behaved just as the eyes of man did. A spate of experimental work began on the eyes of cats, dogs, and other animals which has not quite ceased yet and has sometimes, when dealing with eyes which have practically no accommodation, been misleading. But at an early date observers noted the difference between the ciliary muscle of monkeys and of cats and dogs. 
The first real criticism came from Trautvetter $^{1}$ who in 1866 made a thorough investigation into the nerve control and amplitude of accommodation in the eyes of cats, dogs, rabbits and pigeons and could not find any changes in the images formed on the anterior surface of the lens by any method of stimulation of the nerves supplying the eyes in the mammals. $\mathrm{He}$, however, obtained positive results in pigeons. He examined the eyes after single and double iridectomy. $\mathrm{He}$ repeated the work under the direction of Helmholtz with negative results. He stimulated the various nerves supplying the eyes. But it is interesting to note that even he still suggested that the animals could accommodate but that he had not discovered the method. Eserine was practically unknown for ophthalmic purposes at that date.

But in 1885, applying the then newly discovered method of retinoscopy, W. Lang and $I^{8}$ endeavoured to ascertain the refractive character of the eyes of mammals and examined 185 eyes of domestic and wild animals including rabbits, guinea-pigs, cats, rats, mice, horses and dogs. The wild animals were Siki Deer (Persia), Cervus (Porcupine), Black Bock (East Indies), Jeannette Cat (South America), Paradoxus Cat (East Indies), Peccari, Hyena, Opossum, Porcupine, Australian native cat, Jackals, Mongoose and thirteen Monkeys. In the course of this examination we found that in animals other than monkeys there was no evidence at any time of any change of refraction due to accommodation.

Theodore $\mathrm{Beer}^{20}$ next investigated the methods of accommodation in the animal kingdom. He found that in mammals, after the primates who possess good accommodation, the others follow at a considerable interval. It attained the highest degree in animals other than primates in cats and other carnivora. As a general rule in the large eyed animals-the solipedes-the ruminants-and the whale - the range was $\frac{1}{2}$ to $2 \mathrm{D}$. In cats he found a range of $2 \mathrm{D}$. to $3 \mathrm{D}$.

But Beer makes the significant observation that in every class of animal except cephalopods and aves there are species in which accommodation is absent or is very feeble. In a letter addressed to me he stated that he found accommodation in dogs, cats and a fox. The range was $1 \mathrm{D}$. to $3 \mathrm{D}$., but added that it is difficult to be sure of a change of less than 2D. The errors of the method are obvious, especially to those who have examined animals' eyes by retinoscopy. Beer, however, found no accommodation in the rabbit or the hare. He found extensive accommodation (up to 10D.) in monkeys.

$\mathrm{I}^{13}$ then iridectomised, or doubly iridectomised animals' eyes, much as 'Trautvetter had done, and after their recovery tested their 
refraction by retinoscopy employing atropine and eserine and I checked the result by electric stimulation of the corneal margins. I failed to find any change in dogs, cats or rabbits. With monkeys there was evidence of a range of accommodation of about $5 \mathrm{D}$. In the marsupials, viz., the wombat and the koala-and in one monotreme (viz., the echidna) there was no change. In the native cat (a marsupial) it is impossible to perform an iridectomy but there was no evidence of change. Mr. Lang and I had tested a domestic cat, thoroughly under the influence of atropine. It caught a mouse amongst obstacles without difficulty.

Treacher Collins ${ }^{21}$ in his Bowman Lecture stated that the degree of development of the ciliary muscle corresponds fairly accurately with the degree of accommodation which the animal has been found to possess. In the echidna and the great ant eater the ciliary muscle is practically non-existent. In the rabbit only a few scanty fibres are recognisable. It is rather a commentary on the difficulty of investigation that some observers found accommodation in an animal such as the rabbit which possesses only a rudimentary ciliary muscle.

Fincham $^{27}$ has adopted a novel and ingenious method of investigation. He has photographed images on the anterior surface of the lens both in normal situ and after the suspension of the lens has been removed; comparing the two pictures he found that in monkeys the change was marked but in the pig, sheep, reindeer, rabbit and cat the images were slightly larger, indicating that under tension the anterior surface was slightly flatter than when the tension was removed. He estimated by retinoscopy the accommodation in a rabbit nine months old by applying atropine to one eye and eserine to the other. He found the difference was only 1D. and that the difference in the images was negligible.

Here a note of caution is necessary. Apparently eserine and atropine act as in man, but knowing the biological pitfalls I have never assumed this to be so and have checked the result by electrical stimulation at the corneal margin wherever possible.

Henderson ${ }^{22}$ drew attention to the variations of the ciliary angle in mammals and estimated, by a method not given, the accommodation in the horse and found it not much more than 1D.

Such in brief outline is the history of this puzzling quest. Personally I found no accommodation in the eyes of the animals specified by me. Other observers found also in some instances no accommodation and in others a negligible amount. In the domestic animals Lang and I found errors of refraction amounting to $10 \mathrm{D}$. of hypermetropia and also high grades of myopia and in some cases astigmatism. In the wombat I found $+5 \mathrm{D}$. of hypermetropia. Of what service would an accommodation amplitude of 1 to $3 \mathrm{D}$. be in cases such as these? 
I now set out a summary of the available knowledge of the various methods adopted in the animal kingdom as prepared by the Professor of Physiology in the University of Melbourne (Dr. W. A. Osborne $)^{25}$.

(1) In cephalopods the eyes are emmetropic or slightly hypermetropic when at rest but the lens can be pushed forward by pressure on the vitreous and a myopia of 12D. to $14 \mathrm{D}$. can be produced.

(2) In marine worms (alcyopide) a bulb filled with ocular fluid and communicating with the "vitreous" is capable of being squeezed by contractible tissue and the lens is pushed forward.

(3) In the nautilus the eye is a pinhole camera and there is no lens.

(4) In fish the lens can be pulled backward in active accommodation and the eye accommodated for distant objects.

(5) In periophthalmus which must accommodate in air, the process is reversed.

(6) In amphibia the lens is drawn forward in accommodation by direct muscular action.

(7) Birds and lizards adopt the device of altering the curvature of the lens by direct pressure.

(8) In mammals the device is employed of freeing the tension on the lens and allowing its anterior surface to bulge.

It is a remarkable story and Professor Osborne's comment is apposite, i.e., " the facts form a strange commentary on Sir James Jeans' belief that the architect of the universe is a higher mathematician." Perhaps some day the meaning of this puzzle may be understood.

In the meantime we may well ask how is it if there is an ascending scale of development that the primates have just learnt to do what the birds did long ago and much more successfully.

A word must be said about the gaps and failures in the animal kingdom which Beer noted in 1898. Mayou'6 found in some fresh water fishes no accommodation and apparently there is none in the sturgeon (Hess quoted by Osborne).

I referred in the commencement of this sketch to the mentality following Helmholtz' discovery of the detailed method of accommodation in man. When I prepared the paper published in the Ophthalmic Review in $\mathbf{1 8 9 8}$ at first I submitted it to the Editor of the Journal of Physiology who was so sceptical of the results that he was unwilling to publish it as the conclusions were too heterodox and yet he had done experimental work on the eyes of mammals and based conclusions thereon believing that they could accommodate. Accordingly I sent it to the Ophthalmic Review realising that ophthalmologists would better understand the problem. 
May I finally submit some questions to those interested?

(1) Of what possible value would $1 \mathrm{D}$. of accommodation be to those mammals who possess it even if they could employ the whole of it-an unlikely contingency?

(2) If then it is practically useless why does the accommodation apparatus persist or re-appear?

(3) What is the meaning of the gaps and failures which seem interspersed in the animal kingdom?

(4) Why does the echidna with close reptilian affinities possess neither accommodation nor ciliary muscle, and yet the extensive amplitude in reptiles was set out by Beer and confirmed by me in the case of the Australian blue tongued lizard?

(5) How comes it that the primates have developed a method of accommodation which the birds developed long since and which is inferior to that of birds and how is it that the lower mammals have either lost it or failed to develop it? If we assume that the development of the mammals took place from a reptilian stage the problem is nearly as difficult, though the accommodation in reptiles whilst excellent is effected by methods differing from those in the birds and primates.

In conclusion, if by any flight of imagination it could be suggested that development was under anthropomorphic control it would appear that a set of diverse experiments had been made with a view to supplying these various animals with a necessary piece of apparatus and that no definite or uniform conclusion had been reached. But I prefer to state, with all humility that I cannot even conjecture how this extraordinary result has been obtained: Ignoramus and, I am afraid, Ignorabimus.

\section{REFERENCES}

1. Trautvetter.- " Ueber den Nerv. der Accommodation." Arch.f. Ophthal., Vol. XII (1), s. 95, 1866.

2. HENSEN and VOELCKERS.- " Experimentale Untersuchung ueber den Mechanismus der Accommodation." Kiel, 1869.

3. ADAMUK.- "Zur Frage ueber den Mechanismus der Accommodation " Centralbl. $f$. d. Med. Wiss., p. 292, 1871.

4. Henson and VOelckers. - "Ueber die Accommodations bewegung der Choroidea in Auge des Menschen, Affen und der Katze." Arch. $f$. Ophthal., Vol XIX (1), s. 156, 1873.

5. J. Hock.- " Experimentelle Untersuchungen ueber die Wirkung der Meridionalen (Langs) Fasern des Ciliar Muskels." Centralbl. f. d. Med. Wiss., No. 43, 1878.

6. HirSCHBERG. - “ Zum Vergleichenden Ophthalmoscopie, Vortrag Gehalten in der Berliner Physiologischen Gesellschaft." am February 10, 1882 : Arch.f. Anat. u. Physiol., 1882; Phys. Apth., heft 1 und 2, s. 81 .

7. Jessop.-Proc. Roy. Soc. Vol. XL, p. 478.1886.

8. LANG and BARRETT.-Ophthal. Hosp. Repts., Vol. IX, p. 2, 1886.

9. Helmholtz.-Physiol. Optik, 1866.

10. Wuerdinger.- " "Ueber die Vergleichenden Anatomie des Ciliar Muskels." Zeitschr. f. Vergleich. Augenheilk., s. 121, 1886.

11. LANDOLT.- "Refraction and Anomalies of the Eye." 1888. 
12. Jessop.- "The Physiology of the Intra-Ocular Muscles,"Bericht Ueber die Internat. Ophthal. Congress, 1888.

13. BarRetT.- Transactions Intercol. Med. Congress of Aust., Melbourne, p. $588,1889$.

14. Morat et Doyon.-Arch. de Physiol., p. 507, 1861.

15. LANGLEY and ANDERSON.- " The action of Nicotine on the Ciliary Ganglion and on the endings of the Third Cranial Nerve." Jl. of Physiol., Vol. XIII, p. $461,1892$.

16. "On the Mechanism of the Movements of the Iris." Jl. of Physiol., Vol. XIII, p. $55 t, 1892$.

17. Ricket. Dictionnaire de Physiologie. 1895.

18. Tscherning.-Optiq. Physiol., 1898.

19. Barrett, J. W.- "Do Mammals Accommodate?" Ophthal. Rev.. Sept., 1898.

20. BeER, Theodore.-Wien. Klin. Wochenschr. and Ophthal. Rev., Sept., 1898.

21. Collins, E. Treacher.-Bowman Lecture, 1920. Trans. Ophthal. Soc., Vol. XLI. 1921.

22. Henderson, Thomson.-Doyne Memorial Lecture. Trans. Ophthal. Soc., Vol. XLVI, 1926.

23. WoOD, Jones F.- "The changing point of view." Bancroft Memorial Lecture. Med. Jl. of Australia, August 24, 1931.

24. Barrett, J. W.-Med. Jl. of Australia, Feb. 6 and May 21, 1932.

25. Osborne, W. A.- "A Problem in Biology." Med. Il. of Australia, Sept. $19,1932$.

26. Mayou, M. S.-Brit. Jl. of Ophthal., 1932 and 1933, and correspondence with J. W. BARRETT.

27. Fincham, EdGAR F.-" The Mechanism of Accommodation."

\title{
A MELANOMA OF THE IRIS WITH PATHOLOGICAL FINDINGS*
}

\author{
BY \\ FRED T. TOOKE \\ FROM THE DEPARTMENT OF OPHTHALMOLOGY, \\ ROYAL VICTORIA HOSPITAL, MONTREAL, QUEBEC
}

Melanomata of the iris are not of infrequent occurrence and have been recorded and exhaustively described by Fuchs, Treacher Collins, Gilbert, and Verhoeff, to mention only a few outstanding authorities. They occur, according to Fuchs, under two different forms. The first consists in a blackish tumour which apparently goes out from the stroma of the iris into the anterior chamber and arises from the proliferation of the chromatophores. The second type of melanoma has its seat at the pupillary margin of the iris and develops from the cells of the retinal pigment layer at the spot where it is reflected upon the anterior surface at the pupillary margin. Sometimes in consequence of the pupillary reaction these nodules become separated and detached and lie free in the anterior chamber. This type is not infrequently seen in the horse as has been described by Treacher Collins.

\footnotetext{
* Read before the American Ophthalmological Society, Hot Springs, Virginia,
} June 3, 1937. 